症例

慢性膿胸腔に隣接する胸壁に発生した扁平上皮癌の 1 例

国立療養所山陽病院外科

牧原重喜小谷一敏梅森君 樹

慢性膿胸に合併した扁平上皮癌の 1 例を経験したので報告する.

症例は61歳男性. 主訴は右前側胸壁の瘻孔. 平成元年, 右結核性膿胸に対し胸郭成形 術と大胸筋充填術をうけたが平成 6 年 3 月右前側胸壁に瘦孔形成を認め他院より紹介と なった。胸腔内搔爬術および肋間筋充填術を施行したが胸水が再貯留. その後右胸腔内 に腫瘍性病変が出現, 急速に増大し生検にて扁平上皮癌が証明された.

慢性膿胸の診療に際しては，悪性腫瘍の合併を念頭におき早期発見により予後の改善 に努めるべきと考える。

索引用語：慢性膿胸，扁平上皮癌

緒言

慢性膿胸には悪性リンパ腫をはじめとする悪性腫瘍 が合併することが知られているが扁平上皮癌の合併は きわめて稀である。われわれは，結核性膿胸のため胸 郭成形術および大胸筋充填術施行 5 年後に再発し皮膚 瘻を伴った症例に対し胸郭成形術と胸腔内搔爬術を行 い, 術後経過中胸腔内に扁平上皮癌の合併が証明され た 1 例を経験したので報告する。

\section{症例}

症例：61歳, 男性.

主訴：右前側胸壁瘦孔形成.

既往歴: 平成元年, 右結核性膿胸.

家族歴：特記すべきことなし。

現病歴：平成元年 5 月，右結核性膿胸のため他院に て胸郭成形術および大胸筋充填術を受けた。その後経 過良好であったが，平成 6 年 3 月，右前側胸壁に皮膚 瘻を形成したため某院受診, 精查加療目的で当院紹介 となった。

入院時現症：身長 $153 \mathrm{~cm}$, 体重 $58 \mathrm{~kg}$, 貧血, 黄疸を 認めず. 右前側胸壁に皮膚瘻を認めた．腹部，四肢末 梢に異常を認めず，表在リンパ節に腫脹を認めなかつ た.

入院時検査成績：検血にて白血球数 $9200 / \mathrm{m}^{3}$, 生化

2001年 1 月25日受付 2001年 4 月27日採用

〈所属施設住所〉

干755-0241 宇部市東岐波685
学では $\gamma-\mathrm{GTP} か ゙ 66 \mathrm{IU} / \mathrm{L}$ またCRP3.2mg/dl, $\mathrm{CEA} 6.1 \mathrm{ng} / \mathrm{ml}$ と軽度上昇していた，呼吸機能では VC1.361 (43.5\%)， FEV $1.00 .991(72.8 \%)$ と拘束性障 害を認めた．血液ガス分析はほほ正常で $\mathrm{pCO}_{2} 37.5$ $\mathrm{mmHg}, \mathrm{pO}_{2} 79.0 \mathrm{mmHg}$ であった。

胸部 $\mathbf{X}$ 線所見：右胸郭成形術にて第 $1 \sim 5$ 助骨を 切除されており，大胸筋を充填されているため右肺が 圧迫されていた（Fig. 1)。

胸部 CT 所見：右前側胸壁から右胸腔内の膿胸に連 続する瘦孔が認められた（Fig. 2).

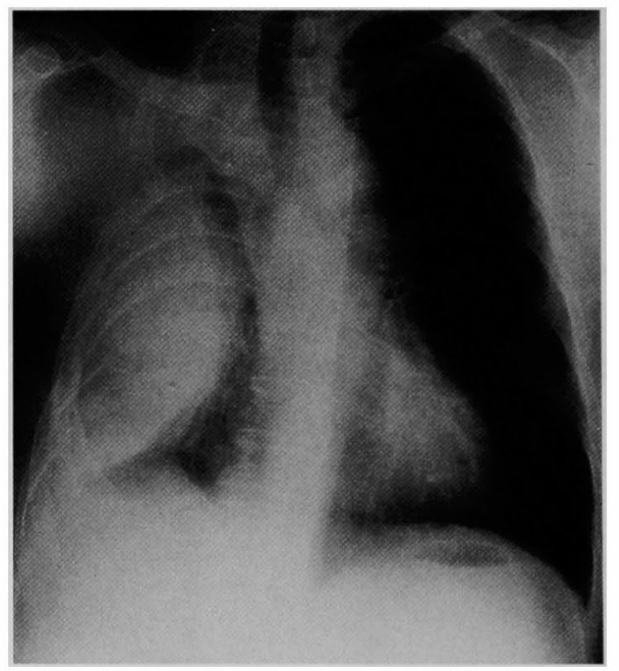

Fig. 1 : Chest X-Ray showing the right pyothorax and compressed right lung. 
疼孔造影・気管支造影所見：瘦孔造影にて膿胸内部 が造影されたが気管支瘦は認めなかった。

入院後経過：以上より結核性膿胸再発と診断，抗結 核薬を投与し，平成 6 年 5 月10日手術を施行した。

手術所見：右後側方切開にて膿胸表層を露出，第 6 肋骨から尾側にかけて前回手術で充填された大胸筋が 硝子化線維結合織化していた。第 6〜8 肋骨を切除し たのち膿胸内を搔爬洗浄，第 $6 ， 7$ 助間筋を弁状とし て充填し胸腔内ドレーン 1 本を留置, 閉胸して手術を 終えた。肉眼的には腫瘍性病変は認めなかった。

術後経過：術後は胸腔内ドレーンより少量の排液が 続いたが徐々に減少，術後14日目にドレーンを抜去す

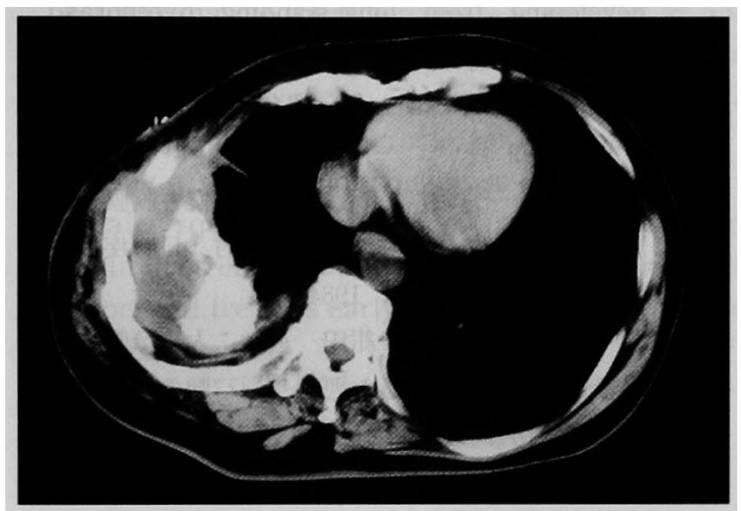

Fig. 2 : Chest CT showing the right pyothorax and the fistula of right anterolateral chest wall.
るもその後胸腔内貯溜液が出現, 胸腔内ドレーンを再 留置し保存的に経過を追った．術後ドレーン排液の細 胞診にて class IIIを示した。胸部 CTでも膿胸腔に隣 接する胸壁に腫㰾を疑わせる病変が出現したため再手 術を予定した（Fig.3）。しかし 7 月29日突然背部痛が 出現，氺アミラーゼの上昇を認めたため急性膵炎を疑 い治療を開始，背部痛は徐々に軽減したが 8 月 3 日に 両下肢の麻㾝が出現した. 胸椎 CT にて第 8 胸椎の変 形を認め血中 SCC が $144 \mathrm{ng} / \mathrm{ml}$ に上昇し血中カルシ ウムも $6.7 \mathrm{meq} / \mathrm{ml}$ に上昇した. 8 月30日 MRI を施行, 第 8 胸椎の圧迫骨折をみとめ脊髄が前後より圧迫され ていた，椎間板は比較的保たれており奉椎カリエスは

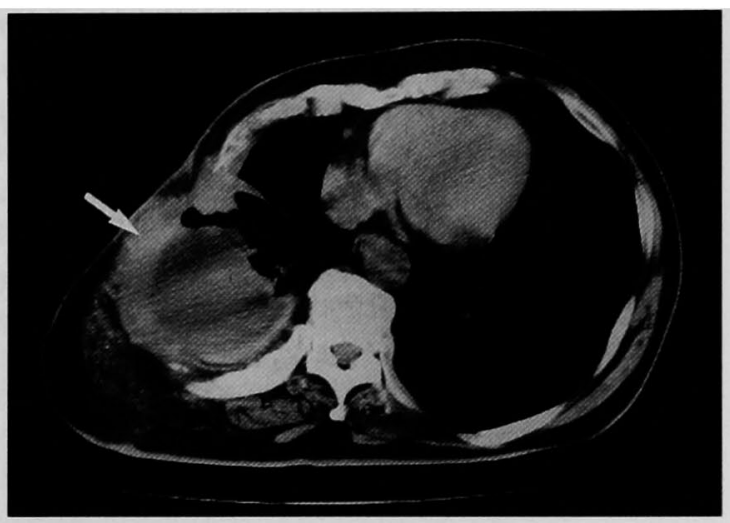

Fig. 3 : Chest CT showing the tumor of right chest wall adjacent to chronic pyothorax (arrow).

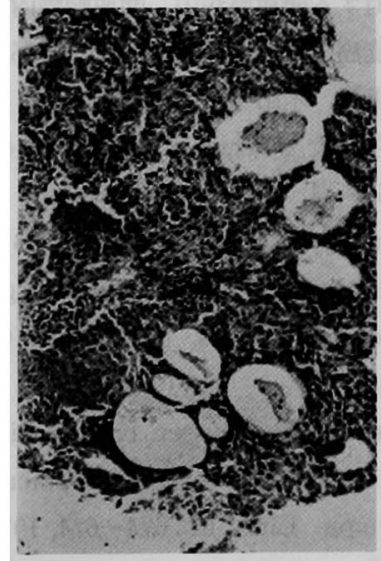

a

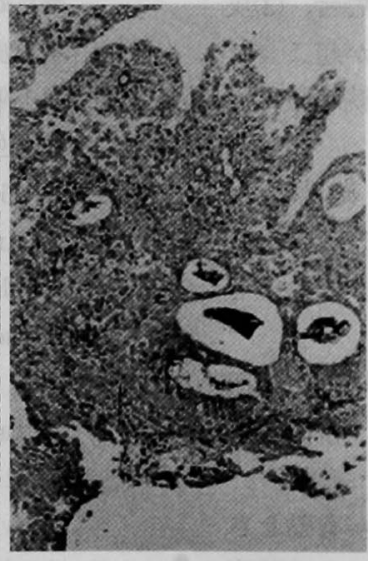

b

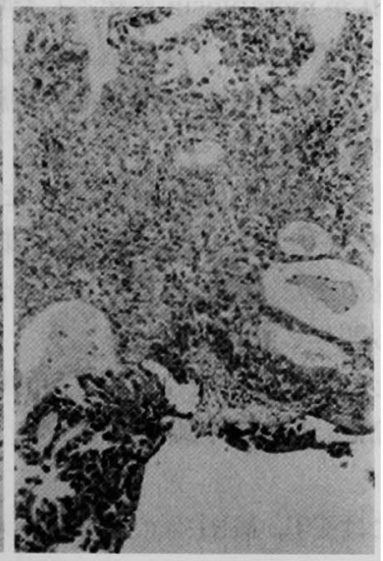

Fig. 4 Microscopic apperance :

a) Marked proliferation of atypical squamous cells with H. E. stain

b) The epithelial mucus stained positive with PAS stain.

c) The portion of the squamous cells stained positive with keratin stain. 
否定的で悪性腫湯の骨転移が疑われた。

以降, 全身状態は徐々に悪化，9月18日, 呼吸不全 にて死の転帰をとった。

病理組織学的所見 (Fig. 4): 平成 6 年 8 月11日, 膿 胸腔に隣接する胸壁腫溜の経皮的生検を行った。

$\mathrm{HE}$ 染色では明瞭な核小体を持っ $\mathrm{N} / \mathrm{C}$ 比の大きな 異型性を持つ扁平上皮細胞が著しい增殖を示していた

(Fig. 4a). 同部のPAS 染色像では, 腺構造を呈す内 腔部にPAS 陽性の上皮性の粘液が見られた（Fig. 4b). ケラチン染色では扁平上皮部分が陽性に染まっ ていた (Fig. 4c).

\section{考 察}

膿胸に合併する悪性腫犜としては悪性リンパ腫がよ く知られており, その他脂肪肉腫, 横紋筋肉腫, 胸膜 中皮腫等の非上皮性腫瘍とともに扁平上皮癌をはじめ とする上皮性腫場の報告も散見されるが稀であ $3^{1)-6)}$.

慢性膿胸に合併した扁平上皮癌（以下本症）は中高 年の男性て膿胸あるいは慢性胸膜炎の長い病悩期間を もつ有瘦孔例が多く，自覚症状としては胸痛を訴える 症例が多いとされている 例14例を集計し，1）平均年齢63歳で13例が男性であ った. 2) 平均31年の膿胸雀患歴があり，10例に皮阒 瘦あるいは気管支瘦がみられた。3）腫瘍形態は腫瘤 形成型と散在性発育型に大別されたと報告している。

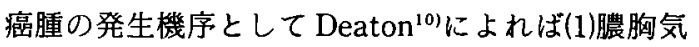
管支瘦を介して metaplasia を起こした場合，(2) mesothelial cell が metaplasia を起こした場合，(3)皮 䖉膿胸瘦を介し皮膰からの上皮細胞の增生が起こった 場合が推測されている．また慢性炎症の持続刺激によ る影響も指摘されている.

本症例の発癌機序は皮膚瘦を認めたため主に Deaton の(3)の機序によると思われるが, 組織の一部 に腺腔構造を認めたため, 気管支瘦は明らかでないも のの(1)の機序も関与したと思われる。

本症の治療としては, 可能ならば外科的切除が選択 されるが, 実際は, 高齢で低肺機能例が多く手術は困 難な場合が多い.

本症の診断には CT, MRI 等の画像診断が有効とさ れる゙1. 本症例では術前画像所見, 手術所見ともに腫瑒

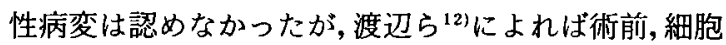
診, 組織診で悪性腫場が疑われたにもかかわらず手術 所見では悪性所見なしと判定された症例もある。従っ て, 慢性膿胸の手術に際しては, 術中の詳細な観察と
十分な組織学的検索を行い腫晅性病変の有無を確認す ることが重要と思われる.

本症例は術後急速に悪化して死亡しており諸家の報 告の如く予後不良であった。

慢性膿胸の診療においては，悪性腫場の合併を念頭 におき，早期発見に努め予後の改善を図ることが重要 である。

結 語

慢性膿胸に合併した扁平上皮癌の 1 例を経験したの で文献的考察を加えて報告した。

\section{文献}

1) Iuchi $K$, Aozasa $K$, Yamamoto $S$, et al : NonHodgikin's lymphoma of the pleural cavity developing from long-standing pyothorax: Summary of clinical and pathological findings in thirty seven cases. Jpn J Clin Oncol $19: 249$ $-257,1989$

2）井内敬二, 一宮昭彦, 森隆地：慢性胸膜炎, 膿胸に発生した悪性腫瘍11例の検討。日胸疾患会 誌 22 (增刊号) : 46, 1984

3）桶順子, 福徳雅章, 紺田 進他: 人工気胸術後 の慢性脤胸壁に発症した悪性リンパ腫の 1 例。臨 血 33:1041-1045, 1992

4) Rüttner JR, Heinzl S: Squamous-cell carcinoma of the pleura. Thorax 32:497-500, 1977

5）井内敬二，一宮昭彦，森隆他：肺結核術後脤 胸に対する開放療法中，開放胸腔内に発生した扁 平上皮癌の 1 例. 日胸臨 $52: 1006-1009 ， 1993$

6）水上陽真，木田厚瑞，福島保喜他：膿胸後, 胸膜 に発生したと思われる扁平上皮癌の 1 例. 肺癌 18:69-74, 1978

7) McAnally AK, Dockerty MB : Carcinoma developing in chronic draining cutaneous sinuses and fistulas. Surg Gynec Obstet $88: 87$ -96, 1949

8) Cattaneo SM, Klassen KP:Carcinoma of the chest wall complicating chronically draining empyema. Chest $64: 673-674,1973$

9）渡辺俊一，山岡章浩，平 明他：慢性膿胸より 発生した扁平上皮癌の 1 例。日呼外会誌 $13: 42$ $-47,1999$

10) Deaton WR Jr: Carcinoma arising in chronic empyema cavity. Case report with review of 
literature. Dis Chest $42: 563-566,1962$

11) Minami M, Kawauchi N, Iio M, et al : Malignancy associated with chronic empyema: Radiologic assessment. Radiology 178:417-
423, 1991

12）渡部 智, 人見滋樹, 和田洋已他：慢性胸膜炎, 慢性滕胸経過中に発生した胸部悪性腫劰手術症例 6 例の検討。日胸外会誌 $37: 281-286,1989$

\title{
A CASE OF SQUAMOUS CELL CARCINOMA ASSOCIATED WITH CHEST WALL ADJACENT TO CHRONIC PYOTHORAX
}

\author{
Shigeki MAKIHARA, Kazutoshi KOTANI and Yoshiki UMEMORI \\ Department of Surgery, National Sanyo Hospital
}

A case of squamous cell carcinoma associated with chest wall adjacent to chronic pyothorax is reported. A 61-year-old man was admitted to the hospital because of a right anterolateral chest fistula and right pyothorax in 1994. He had recieved a right thoracoplasty and a prombage of the right major pectralis muscle for tuberculous pyothorax at another hospital about 5 years before admission. After examinations, a right $6 \sim 8$ th rib resection and a curettage of pyrothorax were performed under the diagnosis of chronic pyothorax. After the operation, pleural effusion appeared again and a rapidly enlarging right intrathoracic tumor was found. Cytology of the pleural effusion revealed class III, offering a suspicion of squamous cell carcinoma. Histological examination of the intrathoracic tumor revealed squamous cell carcinoma. His general condition worsened gradually, and he died.

In the treatment of chronic pyothorax, we must pay attention to the possible association of malignant tumor, and treat as early as possible if it is present, because the associated malignant tumor has a poor prognosis. 